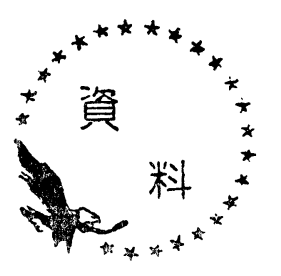

\section{I . ま か がき}

通産省の産業構造調查会総合エネルギー部会は, 旧 臘23日に部会報告書を通産大臣に答申した。この報告 書は, わが国の 10 年間に亘る各種エネルギー産業の進 むべき方向に関し，政府の施策の実施を要請したもの である。本号でその内容を紹介するものとすれば，む しろ事務局を勤めた通産省関係官をわずらわす方が妥 当であるが，関係エネルギー産業の立場から解説を試 みよとの命であるので, あえて筆を執つた次第であ る。それにしても本誌の読者のすべてが部会報告書を みられているわけでもないので, 矢張り本文としても 報告書の概要をお伝えすることが中心とならざるを得 ない仕儀となることをあらかじめお断わりしておきた い。

戦後産業復興の基礎的物資としてエネルギーの供給 確保が優先的にとりあげられ，、わゆる石炭の傾斜生 産が政策として決定せられた。その後わが国経済の早 期自立が叫ばれ，25年から石油製品の自給体制が政策 化せられた。以来石炭と石油は相反発しつつエネルギ 一政策のなかにおいて取扱われてきたが，年月の経過 とともにわが国のエネルギーの需給事情は大巾に変化 をとげ, 数年前までリリーフピッチャ一的立場におか れてきた石油が，まさに主戦投手の地位を占めるよう になつた。この間政府においては, 経済発展とエネル ギー確保の必要度の高いことに留意して, 過去幾度か エネルギー政策を立案してきた。その当初においては， 国内エネルギーである石炭と水力の開発に重点が指向 されたのは当然のことであつたが，これらの考方方の 基本が物量としてのエネルギーの確保にとらわれ，工 ネルギーの経済性の問題は閑却されていた。これが後 日，石炭産業が苦境伯追い込められ，多額の資金を再投 入して再建をはから衩ばならない原因となつたのであ る。通産省産業合理化審議会エネルギー部会は 31 年 12 月「長期エネルギー需給見通し」を発表したが，この 段階でもまだ経済問題としてエネルギーを取扱つてい
U. D.C. 620.9

\section{新エネルギー 政策}

石油盟連 佐 藤 武 男

なかつた。また 33 年 5 月発表の経済企画庁の 経済審 議会エネルギー部会の答申「新長期経済計画」も物量 需給にとどまっていた。ところが 35 年 5 月の経済審 議会エネルギー部会の「エネルギーの長期展望」,35年 11月の「国民所得倍増計画」において初めてエネルギ 一の経済性の追及が示唆せられ, 若干の経済計量が試 みられた。以来エネルギー政策に限らず，エネルギー 市場において急速にエネルギーの経済性が問題化する ようになつた。このよらな経済に目覚めたエネルギー 論が広く行なわれるにいたつた原因は, 価格的に安 く，数量的にも供給力が十分にあると目された石岌 が，国の中のエネルギーバランス上からの制約もあつ て多用せざるを得ない環境におかされたことを無視す ることはできない。

今回の総合エネルギー部会報告は, エネルギーの経 済問題を深くとらえて, 各種エネルギーの位置づけを している点が, 従来の観念的なものにくらべ前進して いる。また石炭, 電力などについては, すでに各審議 会をつうじ将来に対する基盤が与えられていたが，石 油については従来具体的な検討は行なわれておらず， 数量的補給論に終つていたのであるが，今回はその掘 り下げや判断に批判はあるにしても，一応石油の経済 性, 石油産業のあり方にまで言及しているところが特 徴といえよう。報告書は本文だけで数 10 頁, 附属資 料71表におよぶ龙大な労作であり, 総論から初まり石 炭, 石油, 電力, 原子力, 家庭用エネルギー, エネル ギー課税と各個に論及されている。その論旨は全エネ ルギーにわたり網羅的であつて, 特にエネルギー政策 の重点を捉えることがむずかしいと思われる。本誌の 性格からすればそのすべてを紹介しなければ体をなさ ないのであるが，紙数に制約があるので，総論と将来 のエネルギーの中心となる石油に重点をおきながら， 石炭, 電力, 原子力などについても従来の政策判断以 上の部分について紹介し，若干の注書きを行なつてみ たいと思う。 


\section{第 1 表 一次エネルギー供給の見通し}

（換算単位 : $7,000 \mathrm{kcal} / \mathrm{kg}$ 石炭換算 $10^{3} \mathrm{t}$ )

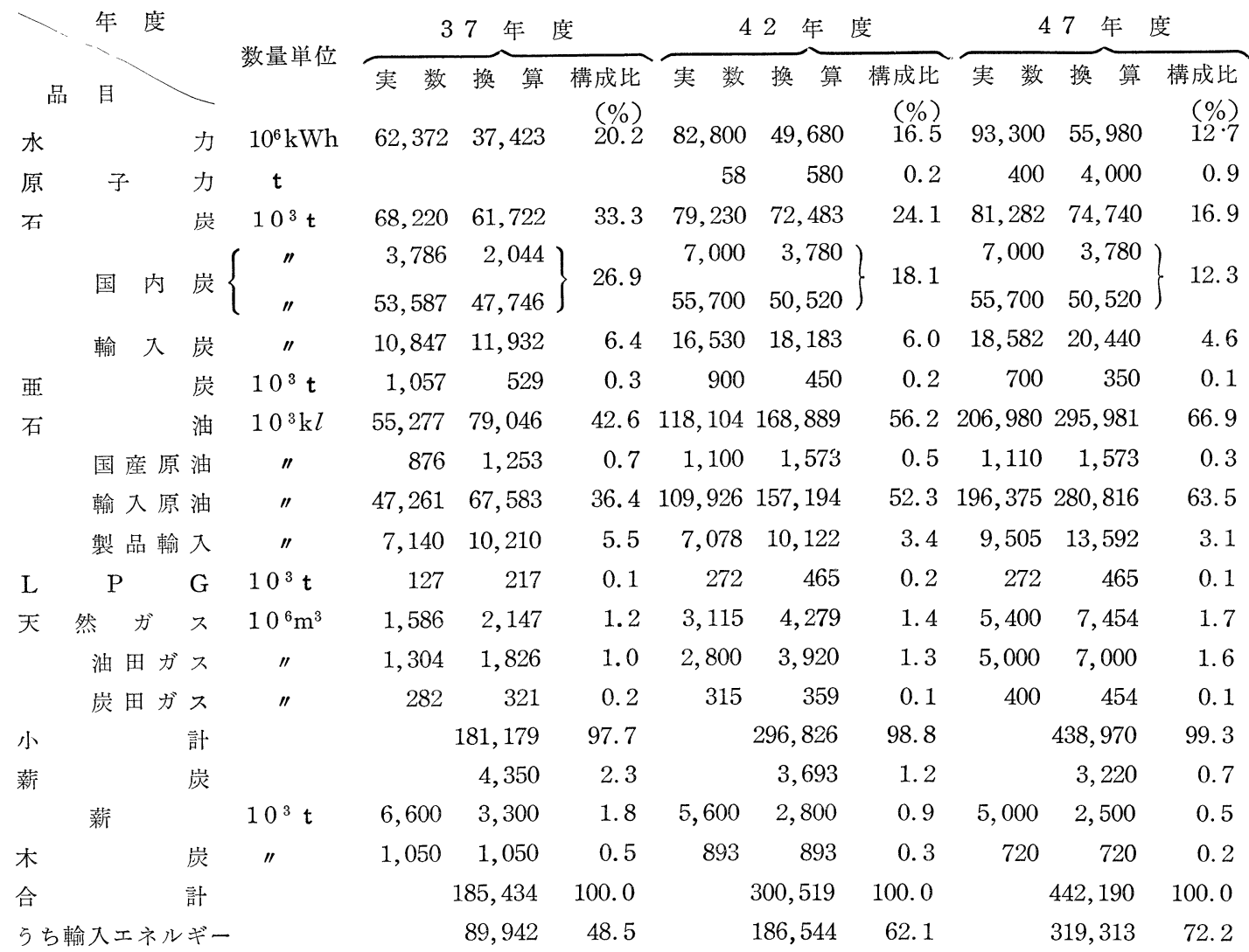

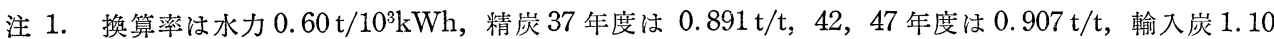
$\mathrm{t} / \mathrm{t}$, 雑炭 $0.54 \mathrm{t} / \mathrm{t}$, 亜炭 $0.50 \mathrm{t} / \mathrm{t}$, 石油 $1.43 \mathrm{t} / \mathrm{k} l, L P G 1.71 \mathrm{t} / \mathrm{t}$, 油田ガス $1.40 \mathrm{t} / \mathrm{m}^{3}$, 炭田ガス $1.14 \mathrm{t} / \mathrm{m}^{3}$ ，薪 $0.50 \mathrm{t} / \mathrm{t}$ ，木炭 $1.00 \mathrm{t} / \mathrm{t}$, 核燃料 $10,000 \mathrm{t} / \mathrm{t}$ (天然ウラン換算）

2. 輸入原油には都市ガス㧍よび硫安用原油が含まれる

3. 国内炭上段は雑炭で外数

4. L P G は輸入分のみを一次エネルギー供給とした。

\section{II . エネルギーバランスの想定}

本報告書は将来 10 力年にわたるエネルギー政策を 論じている。その前提として 10 カ年間のエネルギー 需要を想定しているが，これをどの種類のエネルギー で供給することが，エネルギーの経済性，供給の安定 性等の上から望ましいかを勘案して行なつている。報 告書は総合エネルギー政策の基調を带しつつ, まず各 エネルギーについてつぎのような判断を下している。

国内炭に対する考え方：

他のエネルギーと競合せずに存続し得る石炭の需要 量は 42 年度で 3,000 万 $\mathrm{Mt}-3,500$ 万 $\mathrm{Mt}, 47$ 年度では
2,900 万 $\mathrm{Mt}-3,400$ 万 $\mathrm{Mt}$, 程度と推定する。しかし このような水準にまで石炭の生産規模が急低下するこ とは, 離職者問題, 産炭地域疲弊問題など社会的摩擦 が生ずるので, エネルギーの安全保障, 社会的摩擦へ の配慮などを勘案して，37年の石炭鉱業調查団答申と 同様 42 年度までは 5,500 万 $\mathrm{Mt}$ の生産規模を維持する ことが必要であるとしている。また 43 年度以降も 5,500 万 $\mathrm{Mt}$ 程度の横价が妥当と考えるが，なお一層 の合理化を図るべきである。

輸入炭について：

強粘結炭の国内生産量はきわめて少ないので，42年 
度で 1,400 万 $\mathrm{Mt}, 47$ 年度 1,640 万 $\mathrm{Mt}$ 程度の輸入を必 要とし, 弱粘結炭としては 130万 $\mathrm{Mt}, 110$ 万 $\mathrm{Mt}$ 程度の 輸入を必要としょう。

国産原油について：

輸入原油にくらべ大半が割高である。 41 年度では 105 万 $\mathrm{k}$ 程度の生産となろう。

天然ガスについて :

油田ガスは，石油に対し少なくとも現状においては 経済的競争力を持つ国産エネルギーであり, 積極的開 発が望ましい。天然ガスに対する生産は，42年度 28 億 $\mathrm{m}^{3}, 47$ 年度 50 億 $\mathrm{m}^{3}$ が見込まれる。

水力発電について :

経済的開発地点法減少しつつあるが，エネルギー供 給の安全保障, ピーク調整用電力としての優位性も㐫 り，また国土総合開発上の意義も認められるので，今 後もピーク需要の増加に見合つて, 毎年度 80 万 $\mathrm{kW}$ 程 度の開発を進める必要がある。

原子力発電について:

長期的にみて，エネルギーの低廉の原則と安定供給 の原則を兼備するエネルギーとなることが期待され る。本格的実用化に備えて準備段階としての開発を積 極的に進める必要がある。42年度までに $166,000 \mathrm{~kW}$ ， 47年度までに $1,300,000 \mathrm{~kW}$ 程度の開発が見込まれ， 所要核然料は天然ウラン換算で 42 年度 $58 \mathrm{Mt}, 47$ 年度 400Mt となる。

L P Gについて :

L P G は家庭用, 都市ガス用, 工業用として急激な 增加が予想されるが, 今後石油精製業, 石油化学工業 の発展に伴い，国内供給の増大が期待できる。不足分 の輸入量としては 42 年度, 47 年度とも $272,000 \mathrm{Mt}$ 程 度であろう。

輸入石油について：

他のエネルギー源の位置付けを以上のように考えれ ば, 輸入石油は残余の需要を充足するものとして位置 付けられる。その数量は，42 年度で 1 億 1,700 万 $\mathrm{k} l$, 47 年度で 2 億 600 万 $\mathrm{k} l$ 亿達する。輸入石油の一次エネ ルギーに占める比重が大きく，その低廉かつ安定的な 供給の確保がきわめて重要となる。このような観点か ら，海外油田の開発を積極的に行ない，その引取りを つうじて輸入原油処理量の中における比率を高好行 くことが望ましい。

エネルギー部会は，以上のような各個エネルギーに 対する推測および期待の下に 42 年度, 47 年度の一次 エネルギーの供給見通しを算定している

その内容は第 1 表によって判断して頂きたいが，エ
ネルギー供給構成比でみるように石油の比重が 37 年 度 $42.6 \%, 42$ 年度 $56.2 \%, 47$ 年度 $66.9 \%$ となり，ご く近い将来において日本の経済活動が石油を中心に支 えられねばならない点に注目する必要がある。また輸 入エネルギーの総エネルギー供給中に占める割合も， 37 年度 $48.5 \%, 42$ 年度 $62.1 \%, 47$ 年度 $72.2 \%$ となり， この場面でも日本の経済はエネルギーの大半を輸入に 依存することになる。したがつてエネルギーの低廉に して安定した供給確保が国全体としてみて如何に重大 要件となるかがわかることと思う。

\section{III. 二次エネルギー需要}

エネルギ一部会は将来のエネルギー需要について, 国民経済の構造, 過去における経済活動とエネルギー 需要との関倸などから推計を試みている。その 7,000 $\mathrm{kcal}$ 換算 $\mathrm{t}$ 数による需要は 37 年度 1 億 8,779 万 $\mathrm{Mt}$, 42 年度 2 億 9,903 万 $\mathrm{Mt}, 47$ 年度 4 億 2,620 万 $\mathrm{Mt}$ と見積 られている。その成長率は $37 \sim 42$ 年度間で $9.8 \%, 42$ $\sim 47$ 年度間 $7.4 \%$ となり，国民総生産の伸び率と相前 後した伸び率となる。この状態は戦後の国民総生産の 伸長とエネルギー需要の伸長との相関性と類似してお り日本経済とエネルギー需要とがこのように相関をつ ゔけねばならぬとすれば，10年後以降のエネルギー必 要量河可速度的に膨镺し，重大な壁にぶつかるのでは ないかと危惧されるところである。

一次エネルギーの供給構造は別表にみるとおりでめ るが, エネルギー需要の形すなわち二次エネルギーの 段階での種別需要は電力の形での需要が大きい。一次 エネルギーとして投入された石油, 石炭の一部, 核エ ネルギーは電力に転換される。電力需要の比率は 37 年度が $38.9 \%$ であるが， 42 年度では $42.4 \%$ に，47年 度には $47.0 \%$ に増大寸るものと見積られているが， 10年後には使用形態別のエネルギー消費でみると全体 の半分近くが電気の形になることは注目されてよい。 また同様に最終消費が石油の形で使用される比率は, 37 年度の $31.1 \%$ から 42 年度 $36.8 \%, 47$ 年度 $38.0 \%$ に なるとみられている。この場合石炭の形での使用割合 が 47 年度で $11.2 \%$ であるから，47年度のエネルギー 消費は電気と石油で $85 \%$ を占めることとなる点に着目 されたい。

\section{IV．総合エネルギー政策の基調}

エネルギー部会ほ前述したような各エネルギーの位 置付けを行なつたが，その基本としたエネルギー政策 として, エネルギーの低廉の原則, 安定供給の原則, 他の国民経済的利益との調整の 3 点をとり，これらの 総合調整を図つたとしている。 
エネルギーの低廉の原則については，エネルギーが 産業を支える基礎物資であるから，開放経済への移行 を控えて産業の国際競争力を強化するため, エネルギ 一はできるだけ低廉に供給されることが必要である。 現在のわが国の製造業の平均出荷額に占めるエネルギ 一の直接コス卜は $4.3 \%$ 程度とみられるが，これ洁産 業構造の相違を考慮しても, 欧米諸国のそれに比較し て若干大きい。諸外国ではエネルギー供給の低廉化一 の努力が進められているが，わが国も各エネルギー産 業の合理化を促進するとともに，エネルギーの消費者 による自由選択を尊重し，その自由選択を妨げるよう な諸制度は回避されなければならないとしている。

またエネルジーの安定供給の原則としては, 将来の エネルギー供給が前述したようにますます輸入に依存 する度合を高めてゆくことを考えると, 産油国の政治 的不安, 経済外的理由による供給の不安定, 人為的な 価格の引上げなどが安定供給上の問題として理解され る。前者は, スエズ動乱の際において欧州が経験した ように供給の絶対量の不足の問題であり,これをエネ ルギー供給の安全保障の問題と称することもできよ う。後者は, 国際石油資本に対するわが国の精製業資 本の自立性の問題と呼ぶこともできようとしている。

エネルギー部会は, 石油の安定供給について上記の ような認識を持ち, 後の石油政策の筒所でのべられる ごとく, 日本の石油産業は国際石油資本に支配されつ つあり，今後ますますそれが強化される惧れがあると の前提に立つて政策を打出してくるのであるが，われ われは国際石油資本と呼㲎れるものと, 日本の石油精 製業の間柄，また根本的には世界石油事情についてよ く研究してみる必要があると考えるのである。なにが 悪で，なにが善かはエネルギー部会石油小委員会では 具体的に論じられてはいない。それぞれの人がそれぞ れの判断で上記のように決めてかかつたと思われる節 がある。もつとも大切なポイントを, 各自の先入観で 決められたことは遺憾としなければならない。

エネルギー部会は, 上述の判断に立つてまずエネル ギー供給の物量的安全保障として, エネルギーの供給 源を分散化することを提唱している。翰入エネルギー の中心は石油であるが, 現在石油の $85 \%$ は中近東に 依存しているので，これが地域的に分散化を図ること をあげている。しかし前述したように将来 1 億から 2 億 $\mathrm{k} l$ 亿もおよぶ原油をどこに分散化しらるのである らか。世界の石油供給源の現状判断からすれば中近東 以外に手段はないものと思われる。後にソ連石油にも 言及されることになるが，それにもある種の限界があ
ると自認しているとすれば，いかにして中近東石油を 安全に確保するかの政策こそ真剣に検討さるべきであ つて，石油政策のまず第一の問題は将にここにあるべ きであつたといえよう。

つぎにエネルギーの種別分散化をのべているが，国 内エネルギーは資源的制約ないし経済的限界を考慮す ると, これによる安全保障には自ら限度がある。ここ でわが国資本による海外開発原油の確保が重要になつ てくるとしている。海外開発原油は原油供給源の分散 化に資するところ大きく，亡た国際石油資本の原油価 格形式を適正ならしめる機能も期待できるので, 積極 的に考慮され衩ばならぬとしている。果して海外開発 原油が常に成功的のものであるか, また大産油量が得 られたとした場合, 国際的に孤立経営ができ，国際石 油資本に対する牽制機能を持ち得るものであるかどう かさらに十分研究が望ましい。問題はその生産量とそ の時の日本の石油需要に対する比重からその結着はつ くことであろら。

エネルギー部会は, 石油の安定確保の手段のひとつ として邦船タンカーの拡充と貯油水準の引上げを要請 している。この両者を初原油の海外開発事業も巨額 の資金を必要とするのであり，タンカー，貯油ともに 石油コストを引上げる要因を含んでおり，考えること は易いがその実現は仲々むずかしい問題を内包してい るのである。

安全保障の最後に, エネルギー部会は国際石油資本 の支配から脱脚するため, 日本の石油精製業の自主性 の回復を回ることをのべているが，これが具体的方向 は石油政策の項に讓ることとする。

総合エネルギー政策の第三の基本である他の国民経 済的利益との調整として, 炭鉱職者問題と産炭地域経 済問題をあげているが，これらの問題は10 カ年見通 し下においては, 前期の経済的派生事態に対する問題 であると観じ，所要の対策を講ずべきであるが，石炭 産業としては後期の裸になつたときの自立のための合 理化の推進の要をのべている。

また輸入エネルギーの増大と外貨支払いから生ずる 国際収支に言及し，むしろ積極的に低廉な輸入エネル ギーを利用することにより製品コストの引下げを行な い, 産業の国際競争力を強化し, 輸入の防圧, 輸出の 振興を図る方向で対処しなければならないとし，エネ ルギーの直接国際収支の改善に寄与する問題として配 慮すべきことは, 経済性を有する海外原油の開発, 低 廉な価格での原油の輸入, 邦船タンカーによる石油積 取比率の向上などであると指摘している。從来のエネ 
ルギー政策では, 石油の輸入量の増大に伴う外貨使用 の多額化に対し, 常に国際収支を理由として国内エネ ルギーーの依存度強化を主張し,この結果石油輸入は 極力押え，国内炭を優先するといらいわゆる炭主油従 思想が強く，そこにはエネルギーの経済性が省られな かつたのにくらべ, 今回の報告書は初めて低廉エネル ギー主義を貫いている。一国の経済は貿易量の大小に 大きく左右される。その輸入が石油であれ, 他の原材 料であれ，食糧であろうと，その国民の活動性，生活 水準はその国民の得られる国際收支規模で決められて くるのである。原油だけで一国の経済は成立つのでは ない。石油は経済全体の中の一部にすぎない。すなわ ち経済規模, 国力の限度でしか石油は要らないのであ るから，石油の輸入だけをとらまえて国際収支を憂う ることが扔かしいといえる。

エネルギー部会は上述のごとくエネルギー政策の基 本問題に対する考え方を個別に決定しつつ, 最後にエ ネルギーの低廉の原則と供給の安全保障との総合調整 を論じている。すなわち両者を調整する考え方として は，安全保障を損う事態に対する社会保険料として是 認し得る範囲で, 安全保障のための対策を講ずるとい ら考え方によるべきであり，安全保障のための負担が ミニマムにとどまるよう配慮さるべきで，またその負 担の配分が合理的に行なわれるように十分検討されな ければならないと論じている。要するにエネルギーの 低廉の原則を優先すれば，それによつて競合的に影響 を受けるエネルギー産業がでてきて，その弱いエネル ギー産業をつぶしてしまうのでは安全保障の原則が無 となるから，、くらかは割高でも安全保障のためにそ のようなエネルギーを使うべきであるということであ り，この割高分を社会的保険料といらわけである。具 体的には割高は一部の国内炭, また国産原油などがそ れに当てはまり，石炭対策費として計上されている国 費も原油関税を財源としている以上，石油製品の割高 も忍ぶべしということになるのである。問題はこの保 険料率とその配分の合理性にかかつてこよう。

なお新エネルギーである原子力について，石油にく らべ輸送, 備蓄が容易であり, エネルギーの安全保障 の見地からもすぐれたエネルギーであるし, 重油火力 発電にくらべ所要外貨が少なく国際収支上も有利であ るから，長期的なエネルギー政策の方向に沿うものと いえようとしている。

\section{$\mathrm{V}$. 石 油 政 策}

以上総合エネルギー政策の基調を定めたのち, 各個 エネルギーについてそれぞれ政策を提起している。
まず石油の経済的特質として, 石油が現在利用でき る最も低廉なエネルギーであり, 今後相当長期間低廉 エネルギーを持続するであろう。したがつて外貨負担 増問題もあるが, わが国産業の国際競争力強化に役立 たせるべきである。また石油は, すぐれて国際商品で ある。これは石油自体の属性であるが，国内石油資源 に乏しく，所要量のほとんどを海外からの輸入に依存 しなければならないわが国の立場からみるとき，それ は一層きわ立つたものとして立ち現われると判定し， 石油政策の具体案を以下に列挙している。

ここで石油の低廉性については理解できるのである が，すぐれて国際商品であるという意味が抽象的でわ からないところである。立案者が国際商品なる語を如 何に了解しているのか，またこれを読む者がなんと受 取るかによつて石油政策は分岐点に立つことになろ う。石油製品が世界にあま视く普偏的利用度を持つ必 需品の性格を持つているという意味なのか, 普偏性が 高く, しかし少数の国際石油会社によつて生産, 輸 送, 販売を支配されている特殊な環境下にあるという 意味なのか，または産油国と消費国が違つているとこ ろから国際的視野でこれをみつめ数ばならぬとの意で あるかなど解釈に苦しむのである。一番大切な部分を ぼやかしている点注残念である。

石油の安定供給の確保：

総論で述べられたように，輸入先の分散化により輸 入途絶に備えるほか, 海外での自力原油開発を推進す ることを薦めている。なおり連石油の輸入は, 供給の 安定性に問題なしとはしないが，原油供給先の分散化 の一つの方法として考えられてよいであるうとしてい る。つぎにタンカー船腹の確保対策として部船の増強 の必要性を唱つているが, 邦船が現在外船にくらべ 10\%程運賃の高いことからして，海運業の一層の合理 化と国家としても巨額な必要資金の円滑な調達, 助成 の必要性を強調している。また貯油水準を今より高め ることを希望しているが，貯油に伴う巨額な設備資金 の調達とそれに因る経費増の負担などについてはさら に検討を進めるべきだとしている。タンカー，貯油な ど物理的供給安定対策はいずれも重要な問題であり， またその資金が実に巨額に達すること，貯油のための 用地の大きなことも無視し得ないのであつて，ただ単 に効能書だけの羅列に終るのでは困るのである。まだ 後にも金のかかる対策がでてくるが，そのなかのひと つでも実行に移すのでなければ画飴に帰するである う。

国産原油については，その増産には多くを期待でき 
ないし，またそのコストの合理化も限界にきているの で，輸入原油との間の割高分の補償については具体的 な対策が早急に検討実施さるべきであるとしている。

石油製品価格の低廉性の確保 :

日本の石油製品の税抜き卸売価格を欧米諸国のそ礼 と比較すると, 水準自体としては欧米のそれよりも低 位にあり，特に軽質油が著しく低くなつている。した がつて諸外国が重油安の軽質油高であるのに対し，日 本の湯合は逆であつて, 重油高の軽質油安となつてい る。わが国では石油にくらべ石炭が割高となっている が, 石炭対策のために石油製品価格を人為的に石炭価 格まで引上げるような政策は採るべきではなく, 安い 石油を利用して経済力を強めるべきであるとしてい る。

このような反省がなぜもつと早くいわれなかつたか がくやまれるところであるが，現実には石炭対策のた めに原油関税を引上げ, また重油関税も引上げる措置 を安易に実施してきたのは政府自身であつたことを想 起したいと思う。

つぎにエネルギー部会は, なお一層の石油製品価格 の引下げを要請している。そのためには後述する石油 精製業の自主性を確保することによつて, 原油を常に 最良最適のものを安価に入手し得る体制を確立するこ と，タンカーの大型化，高速化を推進することにより 運賃の軽減を図ることの必要性を述べている。さらに 製油所規模を拡大することにより精製コストを引下げ る, また販売価格に占める国内輸送コストの大きいこ とを考え, これが節減のため販売機構の簡素化, 流通 体制の整備の必要性を説いている。また以上のタンカ 一の大型化, 製油所の大規模化, 流通経費の節減を実 現するためには, 数多い精製業が各個に拡大されるの ではその実があがらないから，精製業の集約化等協調 体制の確立について一層の努力を傾けることが望まれ る。また政府においても，このような業界の努力を効 果あらしめるよう, 各般の可能な措置を講ずる必要が あるとしている。

述べられいてるごとく，事実コスト引下げの方法と しては装置産業である特性から, また石油製品の需要 が全国にあま社く広範に配給され福ばならぬ必要性か らして大型化や流通機構の是正などは望ましいことで ある。しかしこれは原則論であつて必ず企業が集約化 しなければ如上の効果があげられないものでもない。 問題は統制というきずなの下にあつて効率的な集約や 系列化がどのようにして生みだせるかにあるう。 自由経済体制下にあるならば, より自然に生存体制は
形成ゔけられるであろう。また将来の日本のエネルギ 一供給が石油に比重の重いことからすれば，石油製品 のより安くなる方向は望をしいし, 業者もまた競つて その努力をしているところであるが，この場合石油産 業の過当競争に起因した現在の異状価格を基準にして より安さをもとめられるのであれば，それは石油精製 業の自殺につらずる結果となることを認識されねばな らない。日本の石油精製業が国際競争に打ち克ちつ つ, 将来の龙大な石油製品需要を円滑に供給するため の設備拡大ができるに応わしい適正利潤の供与なくし ては, 石油の安定供給も無に帰するであるう。

エネルギー部会は, 前述したように日本の石油製品 の価格体系が国際価格にくらべ歪んでいるので, ガソ リン価格を相対的に高为, 同時に重油価格を引下げる ことによつて体系最正をする必要があるとしている。 その佂格体系の歪みの原因として, 部会は, 従来わが 国においては軽質油よりも重油に対する需要が強かつ たこと，原油関税引上げの経緯などから，総石油精製 原価の配分が軽質油に軽く，重油に重くなされている 結果であるとしている。しかしこれでは価格体系の歪 みの理由にならず，結果をのべたにすぎない。なにが 故に歪みを生じたかを十分究明せず，単に是正すべし と説いても実行性にそしいとい方る。真因は戦後の石 炭対策として重油の需給を常に抑圧してきたことによ り，重油価格を高位に維持できたことにある。また石 炭対策上して採られた原油関税の度重なる引!上げが, その逃げ場として重油にもとめられたことである。こ のように重油佂格にしわ寄せを可能ならしめたという べきか，またはせざるを得なかつたというべきかは別 として,ガソリン税が石油外の目的のために過大に積 み重礼られたことを知らね水ならない。ガソリン税の 重圧がガソリン価格の引上げを不可能とし，ためにガ ソリン以外に精製コストアップ分を転嫁せざるを得な かつたことである。したがつて石油製品の価格体系を 是正するには, これらの石油税の改善が強く実施され ねばならないのである。

エネルギー部会は, 価格体系是正に関連してさら に，石油製品の自由化が行なわれた場合は，6,000円 $/ \mathrm{k} l$ 程度の重油の流入が考えられるし, 一方火力発電 の面では高い重油を避けて安い原油を生焚きすること も実行可能となつており, この場合の重油の競争価䅂 は 5,500 円 $/ \mathrm{k} l$ 程度である。これから判断するとわが 国の重油価格（注・ここでいう重油とはC 重油の意に 解される) は 6,000 円以下にまで下げる必要が生じよ うと述べている。 
しかし現在值ちに重油価格の引下げを行なうとする と, 各石油製品の得率の関係から, 軽質油特にガソリ ン価格について重油佂格引下げウの 2 倍を上迴る引上 げが必要となるが，このよらなことは低物価政策から の要請などから推して相当の困難を伴うものと考光 る。よつて石油製品の佂格体系の是正は，

石油製品の平均原価の引下げによる重油価格の引下 げ。すなわち平均原価の引下げ分を重油価格の引下 げに用い，重油以外の製品の方には多くを利用しな いような原価配分を行ならこと。

原油関税は無税の方向に向わせるべきであるが，こ 机に伴う税負担の減少を重油価格の引下 げに用い る。などの措置で解洪すべきことを示唆している。

価格体系是正までの間, 過渡的に問題となるのが原 油生焚きと重油の翰入自由化である。

原油生焚きは発電コストを安くするといらメリット があるが，それが大量に行なわれると石油精製バラ ンスに影響してきて，国民経済的なデメリットが生ず る。問題は生焚き量の程度であるが, 高サルファー重 油の製品輸入分の振替わりとしての原油生焚きについ ては差支えないと考えるが，これを超えてどの程度ま で行ならべきかについては，国民経浐的見地から上述 のメリットとデメリットを考虑して決定さるべきであ る。な技実施に際しては, 技術上, 保安上の問題に十 分注意を払うことが望をしい。

また重油輸入の自由化の影響については, 石炭問題 との関係からするしばらくの猶予はあり得るとして も，基本的に注早晚当面しなけ机ばならないことであ るから, その場合は原油関税の引下げを含む関税措置 によつて対処すべきものと考えるとしている。

石油産業の基本的方り方：

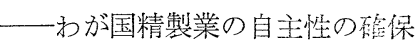

エネルギー部会は, 石油の低廉かつ安定的供給確保 についての個別方策について上述のごとく論じてきた が，最後に日本の石油産業について一つの方向を打ち だしている。このよらな試み活今回が初めてであり， 部会の日本のそして世界の石油に対する認識に対する 結晶といえるものであり，これについてはみなで十分 考えてみる必要のある大切な個所であると思う。

すなわちエネルギ一部会は, 世界の石油市場の現状 は, 原油の過剩傾向, 独立系産油資本, ソ連石油の進 出などにもかかわらず，いわ沛る7大国際石油資本は 産油部門の 6 割を支配し，依然として大きな影響力を 保持している。また精製, 販売部門でも大きな支配力 在確保している。国際石油資本は原油の過剩傾向の中
においても，原油を割骨に維持することによつて産溜 部門の利益を確保するように動いている。

わが国では，原油の過剩傾向のしわ寄せが集約的に 精製販売段階に現出した形になって過当競争に陌り， 精製部門しか持たないわが国精製業の存立の基盤を極 めて弱体なものとしている（注・このような認識が正 しいかでうか疑問である)。

わが国の石油需要注年々急速化増大し，これに応じ 巨額の設備投資を行なわ㸚ばならなかつた。しかし上 述のように基盤の弱いわが国精製業は，この資金を自 己資金により調達することはもとより，国内金融を受 けることもきわ的て图難であり，また他の基幹産業の ごとく財政資金投入の態勢も整えられていなかつたの で（注・誰の責任であるか），わが国精製業は資 金源 を海外一求めざるを得なかつた。この場合，原油の売 込久先醮保に積極的な意欲をみせていた国際石油資本 が，これに資金を供与し，その見返りとして一定量の 原油購入を義務つけるいわゆる原油ひもつき購入契約 が生じたのは，いわば必然的結果であつたといえよ う。そのためかが国石油業の原油購入の自主性は低下 し，37年度において原油購入のフリーハンドは全購入 原油量の $20 \%$ 程度に低下し，今後さらに減少するで あろう。

以上のようにわが国をとり安く産油部門における 国際石沿資本の力はきわめて強大であり，さらに精 製，販売部門においても次第にその力が大きくなつて くる可能性が大きい。このような状況下においては， エネルギーの安定供給の観点からする供給源の分散化 に支障をきたすばかりでなく，低廉性の確保の点から もきわめて問題であると諭じている。

エネルギー部会の石油に対する判断は，日本の精製 業が自己の好まない㣫類の原油を借金するために高く 買わされているとしているが，実体はそらで法ない。 品種の選択も自由であるし，洒格も国際的には安く契 約されている。しかも低金利の資金をまとめて借りら れるし(日本にその能力がない), 原油も長期に安定 確保できるメリットさえある。なぜ外資を利用するの が悪いのであるか判断に苦しむところである。問題は 資本提携なり外資借入に伴う経営への発言権の強大化 の点ではないであろらかと思う。これに対しては日本 の石油政策なり, 日本側資本乃至経営者の態度により 左右し得るむのなのである。

エネルギー部会は, わが国としては最も利潤率の大 きい産油部門について，できるだけ多くのシェアーを 手中に收めることが望むしい。それはまた，わが国に 
おける輸入原油の適正な価格形成にも資するであろう としている。したがつて海外での油田開発を積極的に 行ならべきであるが，特にその調查，探拡の段階はき わめて危除率の高、事業であるから，その促進のため には国が積極的な助成措置を講ずる必要がある。

また石油精製業については，集約化その他合理化を 図り，精製業の体制を整備し，その基盤を強化するた 內所要の石油政策を積極的に進內る必要がある（注・ 所要の石油政策とはなにを指すのかわからない)。こ れらの施策の促進を図るために国においても巨額の財 政資金を積極的に投入する決意が必要である。

さらに長期的尔観点からみると，国の意志を反映し 石油の低廉かつ安定的な供給を図るために必要な機関 として，つぎのような機能を営む機関の設立を目的と する積極的な政策を検討する必要がある。

すなわらエネルギー懇談会が提唱した特殊原油（注 わが国資本で開発した内外原油）の引取，精製，販売 を行ならもの, または持株投資会社で, 原油の引取, 精製，販売を行なら会社に対する投資または子会社の 設立を行ならものなどが例示できるが，さらに海外原 油の偨鉣融資を含む石油供給安定基金の設立なども考 えられる。

エネルギー部会は, 世界の石油産業の趨勢に鑑み, わが国産油業と精製業の有機的連繫をはかるという考 え方を基盤として, 政府はイギリス, フランス, イタ リアなどの積極的な石油政策や上記の諸案を参考とし て,上述のような制度の創設など今後の石油政策を意 欲的に推進すべきであるとしている。

以上がエネルギー部会の石油についての政策論であ るが，海外油田の開発に非常に重点をおいているよう に感ずるが，ヴィジョンとしてその構想が不要だとは 思わないが，果して海外開発が成功的なものであり， 国際石油資本に影響を与え得る程経済的のものである か，またその安定供給が自己の資本によるものである からといつて安定であるかどうかきわめて疑問なしと しない。その成功は祈りつつも, 現実に日本に供給さ れている外国資本による原油が，石油供給の大宗をな しており，これが安定供給こそ第一義的に対策されね ばなら好と思われるのに，それに対しては拘束性 が強いとしてこれを排除しょうと意識しているが，こ のような感覚と態度で果して 5 年, 10 年の間石油の安 定供給注保障され得るものであるかを惧れるものであ る。

\section{VI. 原子力政策}

原子力については当面発電用エネルギー源としてこ
れを評価しているが，その低廉原則の面では，今後の 技術の進歩と原子力発電方式の改良による原価低減の 可能性が大きいこと, 機器, 材料の国産化, 経験の集 積により設計施行の合理化, 工期の短縮などによる原 価低減が見込まれ, 昭和 45 年前後にはほぼ重油専焼 火力と競合し得るようになるものと考える。

安定供給の原則の面からは, 核然料は当面海外飞依 存せざるを得ないが，現在の世界の核然料物質の埋蔵 量および供給能力からみて, 当面わが国が必要とする 原子力発電用の核然料の確保は容易であると考穴られ る。石油との比較も試みたが, 備蓄の面では重油の数 分の一, 輸送費においては数千分の一にしか過ぎない ことがわかつた。さらにウランから転換されたプルト ニウムを発電に利用できるようになれば，ウランのほ とんど全量を活用できることとなり，有利さは増すこ とになる。

原子力は供給の安定性も高いし, 低廉性も大きく期 待できるので, 将来のエネルギー供給源の有力な担い 手となるであろう。したがつて将来に備えて, 昭和 45 年頃までの準備段階における原子力発電の開発を積極 的に進めてゆく必要があるとしている。

エネルギーのつぎの時代は原子力であると喧伝せら れている。しかもその時期は目眉の間といわれる。上 述された中で, 部外者として十分わからない点は供給 の安定性と価格の点である。世界情勢の変化にもよる が，原子力は戦略物資としてスタートしており，その 供給能力のある国は限定されている。核然料が世界的 に石油のように普偏化したとき, 供給の独裁が生れな いかどうか。また現在価格が商業ベースのものである のか, 政策価格であるのかなど, 手放しに核エネルギ 一に対し安心観が持てない感じがする。

\section{VII. 石 炭 政 策}

エネルギー部会は，42年度までを前期と呼び，石炭 の前期対策としては，37年10月の石炭調查団の答申に 沿つて, 現在実施されている諸対策を講ずることとし ている。今回の報告で 43 年以降の後期の政策が提案 されているので，それを紹介しておくこととする。

前期の諸施策により石炭鉱業の安定化と自立への基 盤ができ上り, 社会的摩擦についての配慮の要請は減 退すると考えられるので, 後期政策は低廉と安定の原 則に基づいて検討されるばならない。

国内炭の生産規模は 5,500 万 $\mathrm{Mt}$ 程度を維持するこ とが妥当と考える。この生産規模を維持するために は, 前期に引続き石炭の長期引取りについて大口需要 業界の協力が要請されるが，この場合のエネルギーの 
割高は社会的保険料として是認されるべきであるが， 石炭産業としても合理化効果をできるだけ価格面に反 映させるべきである。石炭産業は産炭地周辺で重油な ど競合エネルギーと十分競争できるような価格の下で 需要の桩大をはかるべきである。重油ボイラー規制法 は廃止す心゙きであり, 一般炭, 無煙炭の自由化は当分 延期するが，原料炭は比較的早期に合理化効果が期待 できるので, 関税など必要な措置を講じた上で自由化 すべきである。

\section{VIII. 電 力 政 策}

エネルギー部会の電力に対する政策は, つぎの諸項 に要約できる。

電力需要が依然としてかなりの増加を続けてゆくこ とを考慮すれば, 電力不足が経済成長の险路とならぬ よう量的充足を確保する必要がある。

電力の二次エネルギー全体に占める比重がますます 増大してゆくことを考慮すれば, 電力料金の長期低位 安定を推進しなければならない。さらに今後の産業の 高度化, 生活の近代化に伴い低廉供給とともに, 供給 電力の質的向上が一層必要となる。

電力が貯蔵不可能のエネルギーであることを考慮す れば, 使用する一次エネルギーの多様化をはかること が必要である。なお電気事業者が一次エネルギーの大 口需要者であることに鑑み，単に電力の安定供給のみ ならず，わが国のエネルギー全体としての安定供給に ついても側面的に配慮することが要請される。

如上の政策の実現のため, 電源開発資金の調達の円 滑化をはかること, 自家発電, 共同発電の活用をはか ることによる電気事業者の負担の軽減, 広域運営の拡 充強化, 内部留保その他企業の合理化の推進, 石炭の 長期引取り量の増加に見合う石炭火力の開発が必要で ある。
エネルギー部会は, 以上各個政策を決めた上で, 最 後にこの総合エネルギー政策の結論は, 現在のような 石油の供給過㮃傾向が少なくとも今後相当期間継続す るとみるのが一般的であるので, その基本的方向は誤 りないものと信ずる。しかしさらに長期的に考える と, 石油の供給過剩が終り不足傾向に転ずるとの意見 もある。この点については, 今後世界的視野に立つ て，一層長期的のエネルギーバランスについてさらに 検討が行なわれることを希望する。また政府は, 以上 述べてきた総合エネルギー政策の趣旨を尊重して, 早 急に具体的措置を検討樹立し, 強力に関係業界の指 導, 助成, 監督を行ならとともに, 政府施策の早急実 施を要請して結んでいる。

\section{IX.むすび}

以上エネルギー部会報告の概要を伝えたが, 要約化 したため報告書の持つニューアンスとの間にずれが生 じたのではないかといらことを惧れる。

エネルギー部会の労作に対し, 批判を加えたことは 越権であつたかも知れ妨, 要所要所で私見を付加し た。なおこの報告で競合，非競合エネルギーにグルー プわけして判断を下したことは賢明な方法と思うが, さらにエネルギーを動力用, 熱用, 原料用に区分して 競合関係を究明したならば, より一層エネルギーの有 効利用に対する判定が明らかとなり，各エネルギーに 対する考え方も異つたのではなかろらかと思う。私見 をいえば，石油エネルギーはその有效利用上からし て, 内然用動力燃料と化学原料にウェイトをおき, 共 通的熱エネルギーとしては原油の生焚きなど天然資源 の奪略使用を回避して，核エネルギーに依存する方が 正常なのではないかと考える。ただし核エネルギーを 熱源とする場合, その所要量と供給の安定性にはなお 一考を要する点はあるものと思われる。

\title{
New Energy Policy
}

\author{
by Takeo Sato
}

(Petroleum Association of Japan)

SYNOPSIS : - The All-out Energy Section of Industrial Structure Committee, an advisory body of Minister of International Trade and Industry has recently submitted a report regarding the way that the all-out energy industries should take during the next decade, for which the Section requested the Government's execution of the policies. The author first outlined the report, then introduced policies of coal, electricity and atomic power with special emphasis on the petroleum policy which may be taken as a main subject, and finally commented these policies. 